University of Nebraska - Lincoln

DigitalCommons@University of Nebraska - Lincoln

Sociology Department, Faculty Publications

Sociology, Department of

Spring 4-20-2020

\title{
Adjusting the Late Policy: Using Smaller Intervals for Grading Deductions
}

Brandon Bosch

University of Nebraska-Lincoln, bbosch2@unl.edu

Follow this and additional works at: https://digitalcommons.unl.edu/sociologyfacpub

Part of the Curriculum and Instruction Commons, Higher Education Commons, Higher Education and Teaching Commons, and the Social and Behavioral Sciences Commons

Bosch, Brandon, "Adjusting the Late Policy: Using Smaller Intervals for Grading Deductions" (2020). Sociology Department, Faculty Publications. 695.

https://digitalcommons.unl.edu/sociologyfacpub/695

This Article is brought to you for free and open access by the Sociology, Department of at DigitalCommons@University of Nebraska - Lincoln. It has been accepted for inclusion in Sociology Department, Faculty Publications by an authorized administrator of DigitalCommons@University of Nebraska - Lincoln. 


\title{
Adjusting the Late Policy: Using Smaller Intervals for Grading Deductions
}

\author{
Brandon Bosch ${ }^{1,2}$ \\ 1 Department of Sociology, University of Nebraska-Lincoln \\ 2 Department of Political Science, University of Nebraska-Lincoln \\ Correspondence: Brandon Bosch bbosch2@unl.edu Department of Sociology, \\ University of Nebraska-Lincoln, 722 Oldfather Hall, Lincoln, NE 68588, USA.
}

\begin{abstract}
Most late policies involve some type of initial large deduction when an assignment is late, followed by subsequent deductions around a certain interval. In many cases, instructors will select $\mathbf{2 4}$ hours as their interval. While this type of late policy is common, it can be criticized for being too punitive. Moreover, large intervals can encourage students to hold on to their assignments longer than necessary, increasing the possibility that students receive a second large deduction. To address some of these issues, I share my experience of using one-point deductions for each hour an assignment is late.
\end{abstract}

Keywords: Late policy, syllabus, late assignments, deducting points

Late polices are a common feature of syllabi (Sulik and Keys 2014) and are sought out by students on the first day of class (Becker and Calhoon 1999). Policies vary, with some prohibiting late work (e.g., Campana and Peterson 2013, p. 64) or forgiving a single assignment (e.g., Atkinson and Lowney 2016, 23-25). Perhaps the most common late policy administers a significant initial deduction such as 10 points followed by subsequent deductions of 10 points for each additional 24 hours an assignment is late, which I will call the 10/24 late policy.

Published in College Teaching (2020)

doi 10.1080/87567555.2020.1753644

Copyright (C) 2020 Taylor \& Francis Group, LLC. Used by permission. 
One of the big issues with late policies is fairness. The rationale for a large initial deduction seems predicated on punitive deterrence. However, Close (1994) argues that fair grading should focus less on punishment and behavioral inducements than having scores reflect content mastery. The grading equity of the $10 / 24$ late policy can also be questioned because a paper submitted 10 minutes late receives the same deduction as a paper submitted 1,400 minutes late. Additionally, given that students are more tempted to cheat when they feel intense time demands (Jones 2011; Simkin and McLeod 2010), we should be mindful of how initial steep deductions might incentivize student cheating.

There is no perfect late policy, but I find using a one-point deduction hourly interval late policy mitigates these concerns. If an assignment is due by Noon, I would deduct one point starting at 1:00 PM, and deduct a total of three points for a 3:30PM submission. The hourly clock runs uninterrupted for 100 hours (roughly four days), when the assignment becomes a zero. Interestingly, the 10/24 system would only deduct 50 points for the same four-day late assignment. However, in practice, the hourly interval system tends to be less punitive because in my experience late work is often submitted minutes or hours past the deadline, rather than days. In an addition to being less punitive, the running meter aspect of the hourly interval encourages students to submit late work as soon as possible, rather than working on it right up to the next 24-hour deadline, which increases the risk for another large deduction. To be clear, this example assumes an assignment is worth 100 points. If the assignment was worth 10 points, one could simply subtract .10 points for each hour late (e.g., an assignment that was 3 hours late could have a maximum score of 9.7 points).

One might worry that this system leads to increased late work. Using this system for three years and across many classes, I have seen no meaningful increase in late work. I think this is because no student wants to lose points (however small), so students will still strive to be punctual. However, the system does have a real impact on student grades, because instead of a student losing 20 points in a semester for turning in a couple of assignments one hour late, the same student would now only lose two points. Importantly, students seem to view this system as being more equitable as well, as I have received no complaints from students about this policy. Overall, I find that a one-point deduction at hourly intervals is enough incentive for students while still minimizing equity problems associated with the 10/24 late policy. 


\section{References}

Atkinson, M. P., and K. S. Lowney. 2016. In the Trenches: Teaching and Learning Sociology. New York: Norton.

Becker, A. H., and S. K. Calhoon. 1999. "What Introductory Psychology Students Attend to on Course Syllabus." Teaching of Psychology 26 (1):6-11.

Campana, K. L., and J. J. Peterson. 2013. "Do Bosses Give Extra Credit? Using the Classroom to Model Real-World Experiences.” College Teaching 61 (2):6o-6. doi: 10.1080/87567555.2012.736885.

Close, D. 1994. "Fair Grades.” Teaching Philosophy 32:361-98.

Jones, D. 2011. "Academic Dishonesty: Are More Students Cheating." Business Communication Quarterly 74 (2):141-50.

Simkin, M. G., and A. McLeod. 2010. "Why Do College Students Cheat?” Journal of Business Ethics 94 (3):441-53.

Sulik, G., and J. Keys. 2014. "Many Students Really Do Not yet Know How to Behave!': The Syllabus as a Tool for Socialization.” Teaching Sociology 42 (2):151-6o. 